\title{
Budaya Paternalistik Dalam Kepemimpinan di Kasepuhan Sinar Resmi
}

\author{
Pudjiastuti, SR. ${ }^{1 *}$ Hidayat, H. $^{1}$ dan Fadli,M. ${ }^{1}$ \\ ${ }^{I}$ Program, Magister PPKn STKIP Arrahmaniyah Depok, Indonesia
}

\begin{abstract}
Abstrak-Penelitian ini bertujuan untuk mendeskripsikan budaya paternalistic dalam kepemimpinan di kasepuhan Sinar Resmi. Penelitian ini dilaksanakan di Kasepuhan Sinar Resmi Desa Sirna Resmi Kecamatan Cisolok Kabupaten Sukabumi. Fokus penelitian ini terletak pada budaya paternalistic dalam kepemimpinan di kasepuhan Sinar Resmi, dengan menggunakan kajian deskriptif kualitatif. Tehnik pengumpulan data dalam penelitian ini menggunakan metode observasi serta wawancara dengan Ketua Adat Kasepuhan Sinar Resmi Abah Asep Nugraha, karenanya dalam pemeriksaan dengan cara observasi dan wawancara dapat ditemukan langsung oleh peneliti melalui partisipasi aktif. Penelitian ini menemukan bahwa masyarakat kasepuhan Sinar Resmi merupakan masyarakat yang terbuka terhadap dunia luar serta kehidupan modern. Hal ini sejalan dengan mulai berkembangnya akses jalan yang lebih mudah, listrik dan sarana komunikasi yang telah menjangkau permukiman warga. Masyarakat juga menjunjung tinggi hukum dan peraturan negara, yang tercermin pada pemakaian ikat kepala bagi kaum laki-laki. Ikat kepala menggunakan kain segi-empat yang merupakan lambang dari empat arah mata angin. Kain dilipat menjadi bentuk segitiga, melambangkan tiga hukum (adat, negara dan agama). Sebagai seorang pemimpin adat yang berkharisma, tentunya Abah memiliki strategi-strategi tertentu untuk melanggengkan kepercayaan dan kepatuhan masyarakat kepadanya. Berdasarkan itulah diperlukan adanya suatu stimulus dari pemimpin yang dapat terus mempertahankan kebiasaan masyarakat dalam melakukan tradisi.
\end{abstract}

\author{
Kata kunci: \\ Budaya Paternalistik, \\ Kepemimpinan, \\ Kasepuhan
}

Histori:

Dikirim: 19 Juli 2021

Direvisi: 29 September 2021

Diterima: 30 September 2021

Online: 30 September 2021

\section{Identitas Artikel:}

Pudjiastuti, S.R., Hidayat, H., \& Fadli, M. (2021). Budaya Paternalistik Dalam Kepemimpinan di Kasepuhan Sinar Resmi. Jurnal Citizenship Virtues, 1(2), 137-150.

\section{PENDAHULUAN}

Indonesia merupakan negara yang menjunjung tinggi nilai-nilai harmonisasi serta keselarasan dalam kehidupan masyarakatnya, sehingga nilai tersebut akan berdampak pada gaya kepemimpinan yang memiliki sifat kebapakan (Irawanto, 2008). Kepemimpinan adalah kemampuan untuk mempengaruhi perilaku seseorang atau sekelompok orang untuk mencapai tujuan tertentu pada situasi

\footnotetext{
$1_{*}$ Corresponding author.

E-mail: yayu.pudjiastuti@gmail.com
} 
tertentu. Kepemimpinan merupakan masalah sosial yang di dalamnya terjadi interaksi antara pihak yang memimpin dengan pihak yang dipimpin untuk mencapai tujuan bersama, baik dengan cara mempengaruhi, membujuk, memotivasi dan mengkoordinasi. Pemimpin adalah individu yang melakukan proses mempengaruhi sebuah kelompok atau organisasi untuk mencapai sesuatu tujuan yang telah disepakati bersama, sedangkan kepemimpinan adalah sifat yang diterapkan individu yang bertindak sebagai pemimpin untuk mempengaruhi anggota kelompoknya untuk mencapai sasaran dan tujuan yang telah disepakati bersama.

Model "triad" yang dikembangkan oleh Cheng dkk (2008) mendefinisikan kepemimpinan paternalistik sebagai gaya yang menggabungkan disiplin yang kuat dan otoritasdengan sikap kebapakan dan integritas moral. Kepemimpinan paternalistik merupakan pemimpin yang perannya diwarnai oleh sikap kebapakan dalam arti bersifat melindungi, mengayomi, dan menolong anggota organisasi yang dipimpinnya. Mengacu pada sikap kebapakan dan otoritas, pemimpin paternalistik membimbing bawahan dengan menunjukkan tingkat moralitas yang tinggi. Dengan demikian, tiga elemen kunci dari kepemimpinan paternalistik menurutnya adalah: otoritarianisme; benevolent; dan moralitas. Tipe pemimpin yang paternalistik banyak terdapat di lingkungan masyarakat yang masih bersifat tradisional.

Popularitas pemimpin yang paternalistik di lingkungan masyarakat demikian disebabkan oleh faktor seperti kuatnya ikatan primordial, extended family system, kehidupan masyarakat yang komunalistik, peranan adat istiadat yang sangat kuat dalam kehidupan bermasyarakat, masih dimungkinkannya hubungan pribadi yang intim antara seorang anggota masyarakat dengan anggota masyarakat yang lainnya. Kepemimpinan paternalistik adalah model yang lebih cocok untuk meneliti kepemimpinan dalam budaya Timur Di mana teori kepemimpinan Barat mungkin menganggap orang-orang cenderung individualis dan menggunakan argumen serta konflik dalam menyelesaikan perbedaan pendapat, kepemimpinan paternalistik dianggap berlaku dalam budaya kolektivis yang menghargai harmoni.

Gaya kepemimpinan merupakan norma prilaku yang digunakan oleh seseorang pada saat orang tersebut mencoba mempengaruhi prilaku orang lain atau bawahan. Perilaku seorang pemimpin yang dapat mempengaruhi bawahannya dapat berdampak positif dan negatif. Sosok pemimpin atau sikap seorang pemimpin yang ada dalam sebuah kelompok masyarakat menjadi sebuah pengukuran untuk kemajuan sebuah komunitas. Masyarakat Indonesia dapat diklasifikasikan memiliki dimensi budaya dengan power distance yang tinggi, kolektivis dimana masyarakatnya menjunjung tinggi nilai kolektivisme yang mempengaruhi hubungan atasan-bawahan seperti interaksi keluarga . Karaketeristik gaya kepemimpinan paternalistik ditemukan di Indonesia, dimana pemimpin publik di Indonesia memiliki peran sebagai orang tua yang bersikap bijak dan jujur. Argumen tersebut didasarkan pada unsur kebudayaan di Indonesia.

Diantara komunitas yang masih menampilkan budaya paternalistik dalam kepemimpinannya adalah masyarakat- masyarakat adat atau komunitas-komunitas adat di Indonesia seperti di Kasepuhan Sinar Resmi Sukabumi.Tipe 
kepemimpinan paternalistik yang kental di lingkungan masyarakat kasepuhan sinar resmi yang masih bersifat tradisional, seperti pada umumnya di masyarakat agraris. Popularitas pemimpin yang paternalistik disebabkan oleh beberapa faktor, seperti: (1) Kuatnya ikatan primodial; (2) "extend family system" (menggunakan sistem kekeluargaan); (3) Kehidupan masyarakat yang komunalistik; (4) Peranan adat istiadat yang sangat kuat dalam kehidupan bermasyarakat; (5) Masih dimungkinkannya hubungan pribadi yang intim antara seorang anggota masyarakat dengan anggota msyarakat lainnya (Sondang P. Siagian, 2006).

Tipe dan gaya kepemimpinan paternalistik ini terjadi hanya dalam suatu kelompok atau golongan yang masih sangat kental dengan aturan adat mereka, seperti dikasepuhan Sinar Resmi ini yang masih sangat tunduk sekali dengan aturan adat, sehingga apa yang disampaikan oleh ketua adat sangat dihormati dan pasti dilaksanakan. Salah satu ciri utamanya ialah rasa hormat yang tinggi yang ditujukan oleh para anggota masyarakat kasepuhan Sinar Resmi kepada Ketua Adat. Karena biasanya orang-orang yang dituakan tersebut memproyesikan gaya hidup yang dapat dijadikan teladan yang baik Dengan kata lain bahwa masyarakat yang tradisional tersebut masih sangat menghormati sekali ketua atau pemimpin adat dalam kelompoknya karena mereka menganggap pemimpin adalah orang pilihan yang dapat membawa kelompoknya kearah yang lebih baik.

Masyarakat adat Kasepuhan Sinar Resmi merupakan masyarakat lokal yang berada di wilayah Desa Sirna Resmi Kecamatan Cisolok Kabupaten Sukabumi. Secara geografis, masyarakat adat Sunda ini tinggal di sekitar Taman Nasional Gunung Halimun Salak (TNGHS). Luas totalnya sekitar 4.917 ha, sebagian besar berupa hutan lindung. Kepala Adat Kasepuhan Sinar Resmi adalah Abah Asep Nugraha. Sejarah Kasepuhan Sinar Resmi memiliki keterkaitan dengan keberadaan Kerajaan Padjajaran dan juga keberadaan Prabu Siliwangi. Kasepuhan Sinar Resmi berlokasi di Desa Sirna Resmi, bersama dua kasepuhan lainnya, Kasepuhan Cipta Mulya dan Kasepuhan Cipta Gelar. Ketiga lepuh ini saling berhubungan dan masih dalam satu garis keturunan. Berdasarkan keterangan beberapa tokoh masyarakat, munculnya masyarakat Kasepuhan berawal dari hancurnya Kerajaan Pajajaran akibat perang dengan Banten.

Sesuai dengan amanat berdirinya Kasepuhan untuk menyelamatkan sistem pertanian Kerajaan Pajajaran, hingga saat ini sistem pertanian yang dilakukan oleh anggota masyarakat Kasepuhan masih merupakan sistem pertanian padi tadah hujan dengan pola tanam setahun sekali. Hal ini pula yang menyebabkan sebagian besar masyarakat masih memilih profesi sebagai petani, sebagian lainnya sebagai buruh tani, serta beberapa profesi lainnya Ada beberapa aturan terkait Leuit yang harus dipatuhi oleh Kasepuhan Sinar Resmi yaitu: (1) Setiap panen 50 unit yang disebut pocong, maka warga harus menyerahkan 1 pocong beras yang setara dengan $3 \mathrm{~kg}$ beras untuk ditusuk di leuit the fetish (komunitas leuit). (2) Aturan untuk tidak menjual hasil panen padi. Biasanya akan diperkirakan berapa lama persediaan beras di Leuit. Dalam kondisi tertentu maka beras diperbolehkan untuk dijual, asalkan beras yang disimpan dapat memenuhi kebutuhan pangan hingga empat tahun ke depan. Hal ini sesuai dengan hasil wawancara dengan Abah Asep (Ketua Adat Kasepuhan Sinar Resmi), yaitu: "......Masyarakat adat Kasepuhan Sinar Resmi memiliki aturan adat yang tidak memperbolehkan 
penjualan beras, beras atau sejenisnya ....." (Sumber: wawancara Juni 2021). Masyarakat adat Kasepuhan memiliki aturan adat yang tidak memperbolehkan penjualan beras, beras atau sejenisnya. Hal ini dikarenakan masyarakat Kasepuhan memiliki tradisi untuk memuliakan padi sebagai sumber kehidupan dan sebagai perwujudan Nyi Pohaci di Bumi. Selain itu, peraturan adat ini menciptakan suasana gotong royong di wilayah Kasepuhan. Jika seseorang tidak memiliki nasi untuk dimasak maka dia dapat mengambil nasi dari leuit komunal.

Sebuah kasepuhan dipimpin oleh tutunggul yang ditunjuk berdasarkan petunjuk gaib (wangsit) dari tutunggul sebelumnya. Ketua kasepuhan tidak boleh menjabat dalam struktur pemerintahan desa agar tidak terjadi kerancuan dalam melestarikan tatali paranti karuhun. Incu putu (keturunan) masya-rakat adat Kasepuhan Banten Kidul tersebar di berbagai wilayah di Sukabumi, Bogor, Lebak, Banten Selatan, Bandung, Jakarta, Cirebon, Kuningan maupun di beberapa kota di luar Jawa. Kasepuhan Banten Kidul merupakan sebuah lembaga adat yang memiliki struktur lembaga dimana masing-masing fungsi memiliki tugas sesuai dengan aturan adat istiadat yang telah dijalankan secara turun temurun. Abah selaku ketua kasepuhan menggunakan lembaga adat dalam menata hubungan yang stabil antara sesama warga (kese-larasan sosial), serta antara masyarakat dengan alam dan lingkungan (keselarasan alam) yang merupakan sumber kehidupan utama. Dengan demikian, akan tercipta perilaku arif dalam lingkungan sosial, menjaga alam dan lingkungan serta kerukunan antar masyarakat. Perilaku arif dalam menjaga lingkungan ini SR.Pudjiastuti(2020) menyebutnya dengan etika lingkungan atau yang disebut keberlanjutan ekologi.

Komunitas adat adalah komunitas yang hidup berdasarkan asal-usul leluhur di atas wilayah adat yang memiliki kedaulatan atas tanah dan kekayaan alam, kehidupan sosial yang diatur oleh hukum adat, dan lembaga adat yang mengelola keberlangsungan kehidupan masyarakat. Salah satu komunitas adat yang ada di Indonesia dan sampai saat ini masih tetap memegang teguh aturan-aturan adat yang menyertainya yaitu komunitas adat Kasepuhan Sinar Resmi, Desa Sirna Resmi, Kecamatan Cisolok,Kabupaten Sukabumi, Provinsi Jawa Barat. Masyarakat adat Kasepuhan Sinar Resmi adalah suatu komunitas dengan segala kearifan lokalnya yang dalam kesehariannya, menjalankan sosial budaya tradisional yang mengacu pada karakteristik budaya Sunda pada abad ke-18. Kasepuhan Sinar Resmi merupakan satu dari sebelas kasepuhan yang berada di wilayah Banten Selatan. Komunitas ini hidup secara turun temurun dari generasi ke generasi, jati diri inilah yang masih dipelihara dan diperkuat sebagai perwujudan rasa syukur dan penghormatan kepada para leluhur yang lahir dari sebuah proses sejarah yang tidak terputus dalam perjalanan masa untuk terus menegakan martabat beserta hak asal-usul sebagai identitas budaya dan warisan budaya nasional. Dengan sistem yang diwariskan para leluhur, masyarakat adat Kasepuhan Sinar Resmi menata seluruh kehidupannya baik sebagai individu maupun sebagai kelompok sosial dan religius yang khas, yang berbeda antara satu dengan yang lainnya. Sistem-sistem inilah yang dipertahankan dan diperjuangkan 
sebagai sumber semangat hidup yang tekandung dalam sistem adat yang masih dibudayakan dan dilestarikan dalam bentuk lembaga adat.

Lembaga adat itu tidak berbentuk lembaga formal sama seperti struktur organisasi biasanya. Dia muncul hanya saat ada masalah yang perlu diselesaikan. Sifatnya fungsional. Yang mana lembaga adatnya, tidak akan kelihatan. Karena tidak ada sekretariat. Lembaga adat berfungsi saat ada acara adat atau musyawarah. Ada yang membidangi urusan hukum. Ada yang membidangi urusan pertanian. Ada yang membidangi urusan ritual. Ada yang membidangi urusan keamanan. Nanti fungsi struktur ini akan kelihatan saat acara adat," Uniknya dalam kehidupan sehari-hari, pemangku adat juga berbaur dengan komunitasnya. "Mereka berbaur. Ikut ke sawah. Ikut nyangkul juga."Atas dasar hal tersebut ingin di analisis terkait budaya paternalistic dalam kepemimpinan di kasepuhan Sinar Resmi.

\section{METODE PENELITIAN}

Penelitian ini dilaksanakan pada bulan Juni 2021, dengan pengambilan data yang berlokasi di Kasepuhan Sinar Resmi, Desa Sirna Resmi, Kecamatan Cisolok, Kabupaten Sukabumi, Provinsi Jawa Barat. Penelitian ini menggunakan metode kualitatif dengan pendekatan deskriptif analalitis. Penelitian kualitatif dengan pendekatan deskriptif analitis dilakukan dengan cara ; peneliti segera melakukan analisis data dengan memperkaya informasi, mencari hubungan, membandingkan, menemukan pola atas dasar data aslinya (SR, Pudjiastuti; 2016). Adapun pengumpulan data dilakukan melalui teknik observasi dan wawancara terfokus baik secara individu maupun kelompok. Validasi data yang didapatkan dibandingkan dengan bahan dan sumber lainnya, Pada bagian analisis data dilakukan proses pelacakan dan pengaturan secara sistematis dimulai dari transkrip wawancara, catatan lapangan dan bahan-bahan lain, sehingga dapat ditafsirkan dan disajikan secara sistematis. Selanjutnya, hasil analisis data berupa pemaparan mengenai situasi yang diteliti yang disajikan dalam bentuk uraian naratif. (SR. Pudjiastuti. 2019).

\section{HASIL DAN PEMBAHASAN}

Pimpinan adalah seseorang yang dapat mempengaruhi orang lain atau kelompok untuk melakukan unjuk kerja maksimum yang telah ditetapkan sesuai dengan tujuan organisasi. Organisasi akan berjalan dengan baik jika pimpinan mempunyai kecakapan dalam bidangnya, dan setiap pimpinan mempunyai keterampilan yang berbeda, seperti keterampilan teknis, manusiawi dan konseptual .Bawahan adalah seorang atau sekelompok orang yang merupakan anggota dari suatu perkumpulan atau pengikut yang setiap saat siap melaksanakan perintah atau tugas yang telah disepakati bersama guna mencapai tujuan. Dalam suatu organisasi, bawahan mempunyai peranan yang sangat strategis, karena sukses tidaknya seseorang pimpinan bergantung kepada para pengikutnya ini. seorang pemimpinan dituntut untuk memilih bawahan dengan secermat mungkin. Situasi adalah suatu keadaan yang kondusif, di mana seorang pimpinan berusaha pada saat-saat tertentu mempengaruhi perilaku orang lain agar dapat mengikuti kehendaknya dalam rangka mencapai tujuan bersama. Misalnya, tindakan pimpinan pada beberapa tahun yang lalu tentunya tidak sama dengan yang 
dilakukan pada saat sekarang, karena memang situasinya telah berlainan. pimpinan, bawahan dan situasi merupakan unsur yang saling terkait satu dengan lainnya, dan akan menentukan tingkat keberhasilan kepemimpinan.

Menurut Agus (2016), paternalisme merupakan sistem yang menempatkan pimpinan sebagai pihak yang paling dominan. Paternalisme tumbuh subur karena dipengaruhi oleh budaya feodal yang sebagian besar wilayah di Indonesia pada awalnya merupakan bekas wilayah kerajaan. Wilayah bekas kerajaan ini memiliki sistem nilai, norma dan adat istiadat yang selalu menjunjung dan memuliakan penguasa sebagai pribadi yang harus dihormati karena, data diperoleh dari beberapa informan tentang peran ketua adat dalam menjaga kearifan lokal di Kasepuhan Sinar Resmi, dalam memberikan motivasi, semangat dan berbagai kegiatan pembangunan dalam pembangunan Kasepuhan Sinar Resmi. Tugas Ketua Adat adalah: 1). membina dan mengembangkan nilai-nilai adat dalam rangka memperkaya, melestarikan, dan mengembangkan budaya; 2). memelihara, melestarikan, dan memanfaatkan kekayaan desa adat untuk kesejahteraan masyarakat hukum adat; 3 ). sebagai pemimpin tertinggi dalam pemerintahan adat; 4). memimpin upacara adat dan keagamaan.

Menurut Gul dan Ayse (2008) Kepemimpinan paternalistic dibagi menjadi tiga dimensi yaitu: (1) Paternalistik Baik Hati (Benevolence): Adalah kepemimpinan paternalistik yang banyak memberikan kebebasan kepada bawahannya untuk berkreativitas guna perkembangan organisasi. Atasan cukup memberikan pengawasan dalam proses kerja. Selain itu, atasan juga menunjukkan kebaikan hati dengan memperlihatkan kepedulian (dalam taraf normal) terhadap kehidupan pribadi bawahan misalnya dengan secara rutin menanyakan kondisi keluarganya. Sebagai negara kolektif, nilai kekeluargaan menjadi penting bagi para bawahan. Oleh karena itu, gaya ini menjadi berperan penting karena banyak bawahan yang menginginkan atasan berperan seperti orang tua mereka. (2) Paternalistik Bermoral (Moral): Adalah kepemimpinan paternalistik yang menunjukkan teladan yang baik kepada bawahan dengan cara mematuhi berbagai peraturan yang berlaku baik peraturan perusahaan maupun norma masyarakat. Atasan dengan gaya ini akan bertanggung jawab dan memimpin dengan memberi contoh yang baik tidak hanya dalam ranah pekerjaan namun juga dalam keseharian pribadi. (3) Paternalistik Otoriter (Authoritarian): Adalah kepemimpinan paternalistik yang berani mengambil keputusan sendiri untuk memberikan yang terbaik bagi bawahan. Dalam hal ini, otoriter yang dimaksud adalah bersikap tegas. Sebagai negara yang termasuk dalam kategori high power distance, gaya ini dianggap efektif karena bawahan cenderung menuruti arahan atasannya.

Dalam kelembagaan adat sunda terdapat konsep Sara, Nagara dan Mokaha, Sara merupakan Urusan Agama, Nagara adalah urusan kenegaraan, kerjasama antar lembaga non-adat dan urusan luar negeri dan Mokaha adalah urusan adat istiadat, kesejahteraan dan pertanian. Ketiga urusan ini saling bekerjasama dalam menyelesaikan urusannya, memiliki tugasnya masing-masing, Sara dipimpin oleh tokoh agama yaitu ustadz yang dalam acara adat selalu memimpin doa, dan urusan keagamaan masyarakat, urusan Nagara dipimpin oleh orang yang ahli dalam diplomasi menyelesaikan permasalahan antara kelembagaan seperti contoh 
dalam permasalahan antara dengan kelembagaan adat (Kasepuhan) dan Mokaha adalah urusan adat istiadat, pertanian, kesejahteraan, tapal batas wilayah yang dipimpin langsung oleh kepala adat yang disebut Abah.

Ketiga kepemimpinan ini konsep unik dalam aturannya tidak bertentangan satu sama lain, dalam konsep ini juga tidak ada yang paling tinggi dan tidak ada yang paling rendah ketiga konsep ini sejajar, karena tiga konsep ini masyarakat adat sering menganalogikan Sara adalah Ruhnya, Nagara adalah Fisiknya dan Mokaha adalah pakaiannya. Maka ketika kelembagaan adat mengabaikan Sara, maka sama dengan manusia yang mati yang hanya ada fisik dan pakaiannya, apabila mengabaikan Nagara maka sama dengan hantu karena tidak memiliki fisik, dan apabila mengabaikan mokaha maka seperti orang gila dan tidak beradab/hewan yaitu tidak berpakaian. Secara bergantian masalah agama, urusan kenegaraan, dan adat ketiga ini saling bergantian menyelesaikan masalah, contoh ketika masalah kenegaraan adat, terkadang diselesaikan oleh bagian kenegaraan adat terkadang oleh kepala adat tergantung kondisi dan situasinya, jika situasinya tidak terlalu penting dan mendesak maka langsung diambil inisiatif namun jika itu membutuhkan keputusan kepala adat, penting dan mendesak maka secara bersama-sama dan berkoordinasi diselesaikan oleh kepala adat secara langsung. Disini komunikasi dan koordinasi penting dalam memecahkan sebuah permasalahan.

Menurut Cangara, Hafied (2013), strategi komunikasi merupakan kombinasi terbaik dari semua elemen komunikasi mulai dari komunikator, pesan, saluran (media), penerima hingga pengaruh (efek) yang dirancang untuk mencapai tujuan komunikasi yang optimal. Strategi komunikasi yang dilakukan Kasepuhan Sinar Resmi adalah komunikasi interpersonal yang dilakukan oleh Ketua Adat sebagai Sumber/sumber utama dalam penyampaian pesan dan keteladanan bagi masyarakat yang masih kental dengan budaya paternalistik. Saluran yang digunakan adalah saluran komunikasi interpersonal. Ada faktor internal dan eksternal yang mempengaruhi strategi komunikasi. Faktor internal terdiri dari: nilai dan norma yang masih dianut, budaya paternalistik yang kuat, peran dominan Karakter Tradisional, dan tradisi Seren Taun yang dilestarikan. Sedangkan faktor eksternal antara lain: Adanya UU No.29 Tahun 2000 tentang Perlindungan Varietas dan Inisiasi Kelembagaan di luar Kasepuhan Sinar Resmi.

Adat Kasepuhan Sinar Resmi Dalam memimpin kasepuhan, Abah mempunyai perangkat adat yang memiliki tugas masing-masing dan sifatnya turun-temurun. Dalam hal ini, perangkat adat yang tidak bisa menjalankan tugasnya lagi akan menurunkan jabatannya kepada keluarganya. Berikut adalah struktur kelembagaan adat yang ada di Kasepuhan Sinar Resmi : 


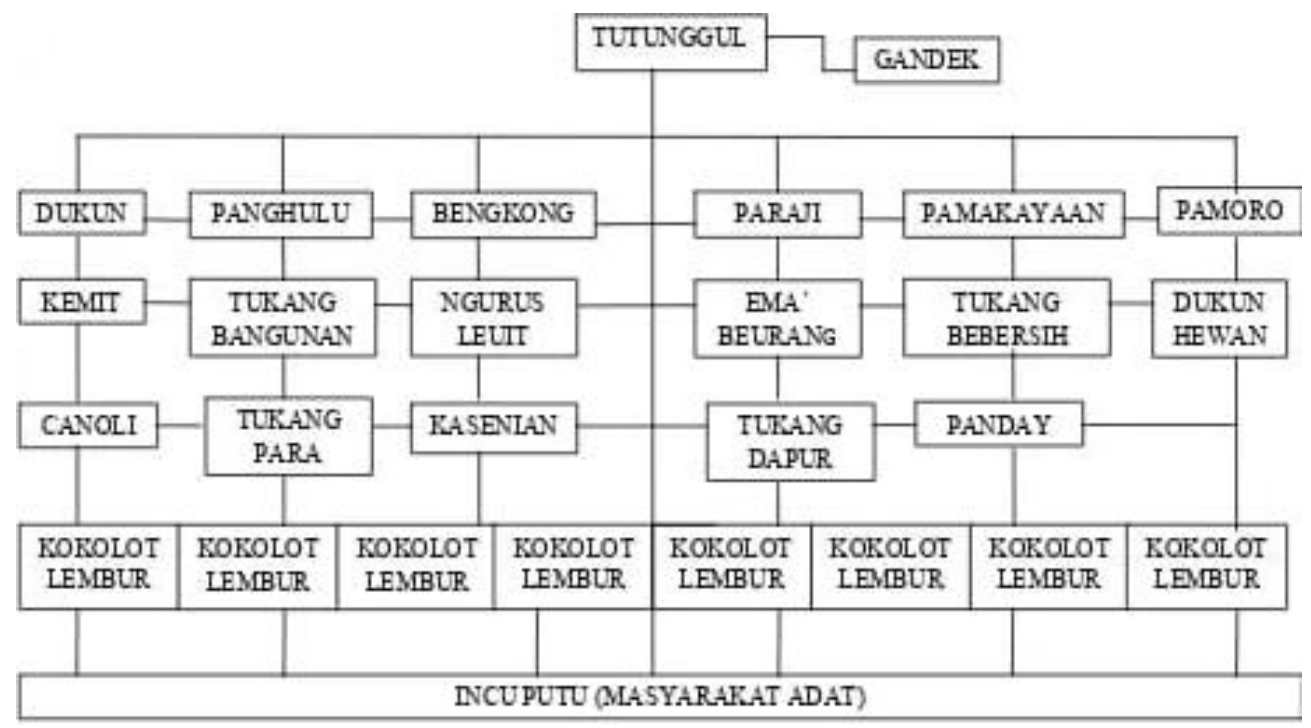

Sumber : Sekretaris Kasepuhan Sinar Resmi.

Gambar Struktur Kelembagaan Adat Kasepuhan Sinar Resmi

Gambar struktur kelembagaan adat di atas merupakan sejumlah perangkat adat yang akan membantu tugas Abah dalam memimpin kasepuhan. Dalam menjalankan tugasnya, Abah dibantu oleh staf ahli penasehat bidang agama dan negara garis fungsional. Secara struktural, di bawah Abah terdiri dari wakil- wakil Abah kokolot lembur, dukun, dan panghulu dan sekretaris. Sekretaris merupakan struktur baru yang dibentuk oleh Abah Asep, tetapi sekretaris tidak termasuk dalam struktur kelembagaan adat di kasepuhan.

Struktur Kepemimpinan di Kasepuhan Sinaresmi yang di pimpin oleh Ketua Adat yaitu Abah Asep sebagai berikut :

1. Tutunggul yaitu Abah Sebagai pemimpin Kasepuhan Sinar Resmi sejak dilantik pada tahun 2002 hingga sekarang Kasepuhan dipimpin oleh Abah ASN, dan berperan menjaga eksistensi Kasepuhan serta menjaga akan keutuhan norma- norma Kasepuhan dan incu-putunya.

2. Gandek adalah Staf Abah ajudan dimanapun Abah bebergian Gandek harus mendampingi kemanapun Abah melangkah. Saat ini Gandek di pimpin oleh Bapak Omid.

3. Dukun selain Apabila ada warga yang mendapat musibah jika secara medis tidak menunjukan sakit maka akan di obati secara tradisional oleh seorang dukun. Dan yang paling penting adalah apabila Abah berhalangan ada, maka tugas abah di gantikan oleh dukun, dan kini di pimpin oleh Bapak Unta.

4. Panghulu yang saat ini di pimpin oleh Bapak Ijat berfungsi sebagai pemimpin do a setiap kegiatan kasepuhan baik berupa salametan ataupun yang ritual Kasepuhan lainnnya.

5. Bengkong bertugas melaksanakan sunatan terhadap anak-anak dari masyarakat Kasepuhan. Di jabat oleh Aki Anuk

6. Paraji adalah Bidan kasepuhan yang bertugas sebagai bidan apabila diantara warga ada yang akan melahirkan, saat ini Paraji di pimpin oleh Mak Ancah. 
7. Pamakayaan adalah seseorang yang mendapat tanggung jawab untuk mengelola huma-serang serta mengatur pelaksanaan berhuma di Kasepuhan, dan adapun Pamakayaan saat ini di pimpin oleh bapak Olis Sunarja.

8. Pamaro yang kini di pimpin oleh Bapak saidi, mengatur keperluan padi huma yang akan di bagi antara incu-putu dengan Abah untuk kepentingan bersama dan akan disimpan di leuit.

9. Kemit di pimpin oleh bapak Sunarja penanggung jawab dalam keamanan lingkungan Kasepuhan.

10. Tukang Bangunan bertugas membuat bangunan baik rumah atau yang berkaitan dengan rancang bangun rumah gede di kasepuhan, dan kini di pimpin oleh bapak Marthu.

11. Tukang leuit bertugas sebagai mengelola keluar dan masuknya padi dari leuit lumbung padi kini di pimpin oleh bapak Suharman.

12. Ema Bangberang bertugas sebagai menjaga terhadap lingkungan secara fisik Imah Gede istana kasepuhan, kini di pimpin oleh bapak Martu.

13. Kabersihan bertugas menjaga kebersihan lingkungan Imah Gede, dibawah pimpinan Bapak Junaedi.

14. Dukun Hewan bertugas sebagai memelihara hewan Kasepuhan atau warga yang ingin memiliki hewan harus izin dan sepengetahuan dukun hewan, dan saat ini dipimpin oleh Bapak Jaja.

15. Canoli bertugas sebagai mengatur ketersediaan beras yang ada di Imah Gede di bawah pimpinan Ibu Rumsih. 16. Tukang Para bertugas sebagai mengatur segala makanan buat upacara yang ada di Kasepuhan, dipimpin oleh Bapak Urna.

16. Tukang Dapur di pimpin oleh Mak Omah bertugas sebagai yang mengatur dapur di Imah Gede mulai membuat makanan dan menghidangkannya baik buat Abah dan keluarganya maupun buat tamu dan atau masyarakat bila ada yang kekurangan.

17. Panday bertugas sebagai yang mengatur semua peralatan baik pakarangan maupun peralatan pertanian di buat oleh panday panday besi saat ini dipimpin oleh Bapak Asta.

18. Kokolot Lembur dipimpin oleh Bapak Martu bertugas apabila adanya tamu maka diwajibkan melalui kokolot lembur, serta bertanggung jawab terhadap incu-putu yang ada di tiap lembur Kasepuhan.

Wujud dari efektifnya gaya kepemimpinan paternalistik Abah Asep sebagai ketua adat Kasepuhan Sinar Resmi adalah dalam pola-pola mempertahankan eksistensi keluhuran warisan adat istiadat yang telah diturun temurunkan beberapa generasi dapat dilihat pada hal-hal sebagai berikut :

\section{1) Lembaga Adat}

Sistem kemasyarakatan di Indonesia, umumnya mengacu pada tatanan aturan yang berada dalam kerangka Negara Kesatuan Republik Indonesia. Meskipun demikian, tidak berarti hal itu menafikan keberadaan tatanan aturan lokal yang diwariskan oleh nenek moyang suatu kelompok masyarakat. Bahkan, ada di antaranya yang lebih dominan mengatur kehidupan suatu masyarakat 
dibandingkan dengan aturan yang bersifat formal. Aturan tersebut biasanya terkristalkan dalam suatu lembaga yang dikenal dengan sebutan lembaga adat.

Lembaga adat adalah sebuah organisasi sosial kemasyarakatan, baik yang sengaja dibentuk maupun yang secara wajar telah tumbuh dan berkembang di dalam sejarah masyarakat yang bersangkutan atau dalam suatu masyarakat hukum adat tertentu dengan wilayah hukum dan hak atas harta kekayaan di dalam wilayah hukum adat tersebut serta berhak dan berwenang untuk mengatur, mengurus, dan menyelesaikan berbagai permasalahan yang berkaitan dengan dan mengacu pada adat istiadat dan hukum adat yang berlaku (BPSNT Bandung, 2001:7).

Berbicara mengenai lembaga adat tentu tidak akan lepas dari konsep tentang struktur sosial. Struktur sosial atau dalam istilah asing biasa disebut social structure adalah suatu jaringan (abstrak) yang mengatur hubungan orang dengan orang di dalam kehidupan masyarakat dalam suatu sistem sosial tertentu (Adimiharja;1992). Struktur sosial biasanya meliputi dasar-dasar keluarga, perkawinan, sistem kekerabatan, status dan peranan sosial, stratifikasi sosial, himpunan yang didasarkan pada kelompok usia dan keturunan, organisasi sosial, kesemuanya itu baik yang dianut masyarakat yang masih sederhana tingkat kebudayaannya, maupun oleh masyarakat yang modern. Sementara itu R.Firth (Meinanda, 1981:25) melihat struktur sosial suatu masyarakat itu terdiri atas dua bagian besar, yaitu kelompok-kelompok sosial atau kesatuan-kesatuan sosial, dan lembaga-lembaga sosial.

Keberadaan suatu kelompok masyarakat yang masih menempatkan lembaga adat sebagai pedoman untuk mengatur kelangsungan hidup mereka perlu mendapat perhatian serta penting untuk diidentifikasi. Bagaimanapun juga, bukan hal mudah bagi mereka untuk mempertahankan lembaga adat dalam dinamika perkembangan zaman.

\section{Kekuasaan dan Wewenang}

Kekuasaan adalah sebuah fenomena seseorang atau sekelompok orang yang memiliki kekuatan atau kemampuan untuk mengatur atau memerintah orang atau kelompok lain yang ada dalam masyarakat. Adapun wewenang diartikan sebagai kekuasaan yang melekat pada diri seseorang atau sekelompok orang yang telah mendapat dukungan dari masyarakat yang dikuasainya (Setiadi dan Kolip;2011). Menurut Mc. Iver bahwa factor penyebab seseorang dapat menguasai pihak lain adalah karena adanya mitos dan hukum. Mitos merupakan kepercayaan yang mengandung nilai dan gagasan yang dimiliki manusia untuk memerintah hidup mereka (1980: 12).

Adapun sumber-sumber kekuasaan dapat diperoleh dari: militer/polisi, ekonomi, politik, hukum, tradisi, ideologi, dan discovery power (Soekanto, 2013:232). Lebih khusus kekuasaan yang diperoleh dari tradisi turun temurun digunakan untuk melanggengkan system kepercayaan dan nilai-nilai yang telah dipercayai oleh pemegang kekuasaan dan pengikutnya. Unsur-unsur kekuasaan dapat dilihat dengan adanya rasa takut, rasa cinta, kepercayaan, dan pemujaan. Dalam system pemujaan orang yang berkuasa mempunyai dasar pemujaan dari orang-orang lain, sehingga segala tindakan penguasa dibenarkan atau dianggap 
benar. Adapun saluran kekuasaan dapat dijalankan melalui saluran militer, saluran ekonomi, saluran politik, saluran tradisional. Melalui saluran ini penguasa menyesuaikan dengan tradisi yang ada di dalam suatu masyarakat yang dikuasainya, dan saluran ideologi.

Sementara wewenang dapat dibedakan ke dalam tiga bagian, yaitu : Wewenang kharismatik, merupakan wewenang yang didasarkan pada kharisma atau kemampuan khusus yang ada pada diri seseorang. Wewenang tradisional, dimiliki oleh seseorang atau sekelompok orang yang sudah lama sekali mempunyai kekuasaan dalam suatu masyarakat tertentu. Wewenang rasional, merupakan wewenang yang didasarkan pada sistem hukum yang berlaku. Sikap dari aktor atau pemangku kepentingan kebijkan (Policy Stacholder) adalah sikap dari seseorang ataupun kelompok yang terkait langsung dengan suatu kebijakan yang bisa mempengaruhi atau dipengaruhi oleh keputusan atau kebijakan tersebut. (SR.Pudjiastuti, dkk.:2021)

\section{Sistem Kepemimpinan Tradisional Kasepuhan Sinarresmi}

Komunitas adat Kasepuhan Sinarresmi dipimpin oleh seorang pimpinan adat yang dipanggil Abah. Abah Asep Nugraha nama lengkap dari pemimpin adat Kasepuhan Sinarresmi saat ini, merupakan pimpinan adat kesepuhan yang dapat ditelusuri dari peninggalan makam karuhun yang ada di Kasepuhan Sinarresmi (Rahmawati dkk., 2008: 173). Beliau merupakan simbol adat kasepuhan yang dijadikan panutan dan tuntunan oleh seluruh warganya. Dalam menjalankan aktivitas pemerintahan adat sehari-hari Abah dibantu oleh seorang wakil dan sekretaris. Selain itu, terdapat juga seorang penasihat ahli bidang agama. Sedangkan secara structural kenegaraan Abah dibantu oleh beberapa orang bawahannya yang mempunyai jabatan dan fungsinya masing-masing.

Mereka terdiri atas dukun, panghulu, kolot lembur, tukang moro, tukang paraji, tukang bersih, tukang suguh, tukang benteng, tukang kemit, tukang goah, tukang sisiuk, dan tukang canoli. Seluruh staf Abah tersebut disebut juga baris kolot atau olot. Menurut Rahmawati (2008: 173), keberadaan sekretaris dalam sistem pemerintahan Kasepuhan Adat Sinarresmi relative baru, yaitu sebagai hasil bentukan Abah Asep yang ditujukan untuk mengikuti arah perubahan zaman. Fungsi sekretaris sendiri adalah sebagai orang yang dapat mewakili Abah dalam berhubungan dengan dunia luar. Selain itu dalam sistem pemerintahan internal, sekretaris juga berfungsi untuk mencatat jumlah warga kasepuhan (incu putu) dan jumlah hasil panen padi yang dihasilkan oleh seluruh warga kasepuhan pada saat menjelang upacara seren taun. Sementara itu kolot lembur ditunjuk langsung oleh abah yang bertugas mewakili Abah di masing-masing rendangan. Menurut Abah Asep saat ini terdapat sekitar 111 (seratus sebelas) rendangan yang ada di Kasepuhan Sinarresmi. Kolot lembur juga bertugas mengelola tanah milik Abah yang ada di wilayahnya dengan sistem bagi hasil. Sebagaimana diucapkan Abah sebagai berikut: "Pami abah tos gaduh leuit seueur, nu ngurus teh tiasa kolot lembur. Nu mimpin rendangan nyaeta kolot lembur. Pami nuju kagok di dieu, tiasa nunjuk ka hiji lembur pang nutukeun eta beas". Para pembantu Abah dalam urusan kerumahtanggaan berjumlah Sembilan orang, yakni (Rahmawati dkk., 2008: 176) tukang moro, tukang paraji, tukang bersih, tukang suguh, tukang benteng, tukang kemit, tukang goah, tukang sisiuk, dan tukang canoli. 
Dari seluruh struktur kepemimpinan adat di Kasepuhan Sinarresmi, hampir seluruhnya diemban berdasarkan keturunan, hanya kolot lembur yang ditunjuk secara langsung oleh Abah. Tentunya dengan kriteria tersendiri sesuai dengan yang diinginkan oleh Abah. "Aturan karuhun kudu dikeukeuhan, dikukukuhan, dipageuhan. Aturanana tilu sapamulu, dua sakarupa, nu hiji eta-eta keneh, kudu diterapkeun kana perilaku urang sapopoe. Kedah ngajaga tekad, ucap, perilaku, sara nagara mokaha kedah kakaulaan" Artinya aturan leluhur harus dipegang dengan kuat. Sebagaimana halnya aturan tilu sapamulu, dua sakarupa, nu hiji etaeta keneh harus diterapkan dalam kehidupan sehari-hari. Setiap niatan, ucapan dan perilaku masyarakat di Kasepuhan Sinarresmi harus selalu terjaga, sedangkan sara, nagara, mokaha harus selalu terlayani dengan baik. Konsep ini kemudian diejawantahkan dalam sistem kepemimpinan adat tradisional di mana staf ahli bidang agama (sara) dan negara dapat melengkapi tugas dan fungsi kasepuhan yang harus menselaraskan antara sara, nagara dan mokaha. Sehingga mereka dapat menjalankan fungsinya dalam melengkapi tugas Abah sebagai pimpinan adat tertinggi (Rahmawati dkk., 2008: 173-174).

Konsep sara, nagara dan mokaha yang terdapat dalam sistem kepemimpinan tradisional di Kasepuhan Sinarresmi memiliki fungsinya masingmasing, yaitu : (1). Sara, mengurus hal-hal yang berkaitan dengan ibadah agama. Oleh karena itu mayoritas di Kasepuhan Sinarresmi beragama Islam, maka pemimpin sara ini disebut kiai. (2). Mokaha, artinya salamet dipimpin langsung oleh Abah selaku pimpinan adat di Kasepuhan Sinarresmi. Abah bertugas memimpin ritual dan upacara-upacara yang ada di Kasepuhan Sinarresmi. (3). Nagara, adalah wakil abah dalam menangani masalah kenegaraan, fungsinya untuk menjembatani kepentingan adat, masyarakat dan pemerintahan desa maupun dunia luar.

Sebagai pemimpin Abah diharuskan melanjutkan pesan dan wasiat dari karuhun kepada para incu putu-nya. Selain menjaga dengan kuat tradisi leluhur khususnya dalam melaksanakan sistem pertanian tradisional, Abah juga senantiasa mengingatkan masyarakat melalui petuah-petuah bijak yang senantiasa diyakini kebenarannya oleh para incu putu-nya. "cing hade dak jaga, cirina urang the mun geus euweuh leuit bakal timbul beurit, mun teu ngukus bakal timbul tikus”. Artinya berhati-hatilah nak, salah satu ciri apabila leuit sudah tidak ada maka akan muncul beurit, apabila tidak memberikan sesajian maka akan muncul juga tikus. Makna dari ungkapan tersebut bahwa seluruh masyarakat di Kasepuhan Sinarresmi harus mampu menjaga keberadaan leuit sebagai warisan leluhur agar tidak tergeser oleh budaya luar, begitu pula berbagai macam ritual yang menyertai keberadaan leuit harus dipertahankan.

Kasepuan Sinarresmi, juga diperkuat oleh adanya sikap patuh terhadap aturan-aturan adat yang dijaga oleh pemimpin adat. Hal ini dapat berarti pula bahwa masyarakat adat Kasepuhan Sinarresmi mematuhi aturan dan perintah Abah. Sistem pelapisan sosial yang bersifat tertutup serta unsur kepemimpinan tradisional yang bersifat pemujaan, di antara masyarakat dan pemimpin adat, menguatkan sikap patuh masyarakat terhadap Abah. Sebaliknya sikap patuh masyarakat terhadap aturan adat yang dijaga oleh Abah, dimanfaatkan untuk melanggengkan sistem kepercayaan dan nilai-nilai yang telah dipercayai oleh pemimpin dan masyarakat adat. 


\section{KESIMPULAN}

Sebagai seorang pemimpin adat yang berkharisma, tentunya Abah memiliki strategi-strategi tertentu untuk melanggengkan kepercayaan dan kepatuhan masyarakat kepadanya. Berdasarkan itulah diperlukan adanya suatu stimulus dari pemimpin yang dapat terus mempertahankan kebiasaan masyarakat melakukan tradisi tatali (ngalung) ka leuit si jimat. Di sinilah faktor pemimpin adat (Abah) sangat berperan khususnya dalam menjaga tradisi-tradisi terkait pertanian dan leuit supaya terus dilaksanakan oleh masyarakat pendukungnya.

Kewenangan tradisional yang dimiliki Abah dalam menjalankan fungsinya sebagai pemimpin adat, memungkinkan beliau menerapkan sanksi adat terhadap pelanggaran-pelanggaran aturan adat. Selain itu Abah sering pula mengiangkan petuah-petuah dan ajaran-ajaran karuhun yang disampaikan baik kepada masyarakat secara langsung ataupun melalui para baris kolot, maupun kepada orang luar yang ingin mempelajari kearifan lokal mereka. Kedua hal tersebut sebetulnya menjadi kunci penting bagi Abah dalam menjaga tradisi dan melanggengkan kekuasaannya.

Kepatuhan terhadap aturan karuhun serta pituah Abah dan para kokolot lainnya, menjadi benteng masyarakat dalam menangkal hal-hal negatif dari luar yang dapat melunturkan ketaatan mereka dalam menjalankan kehidupan yang bersahaja. Sesuai dengan moto hidup mereka cukup sandang, cukup pangan. Hanya perlu untuk hidup berkecukupan sesuai dengan porsinya saja, tanpa harus berlebihan apalagi menghamburkan untuk hal-hal yang tidak perlu.

Strategi komunikasi yang dilakukan Kasepuhan Sinar Resmi adalah komunikasi antar pribadi yang dilakukan oleh Ketua Adat sebagai Sumber/sumber utama dalam penyampaian pesan. Ada faktor internal dan eksternal yang mempengaruhi strategi komunikasi. Faktor internal terdiri dari: nilai dan norma yang masih dianut, budaya paternalistik yang kuat, peran dominan Karakter Tradisional, dan tradisi Seren Taun yang dilestarikan. Sedangkan faktor eksternal antara lain: Adanya UU No.29 Tahun 2000 tentang Perlindungan Varietas dan Inisiasi Kelembagaan di luar Kasepuhan Sinar Resmi.

\section{REFERENSI}

Adimiharja, K. (1992), Kasepuhan yang tumbuh di Atas yang Luruh (Pengelolaan Lingkungan Secara Tradisional di Kawasan Gunung Halimun Jawa Barat), Bandung:Tarsito.

Agus. 2016. Budaya Paternalisme dalam Birokrasi Pelayanan Publik, http://cpps.ugm.ac.id

BPSNT Bandung. 2001. Desain Penelitian dan Pengkajian. Bandung: BPSNT Bandung

Cangara, Hafied, (2006), Pengantar Ilmu Komunikasi, Jakarat: Raja Grafindo Persada.

Cheng, B.S., Chou, L.F. \& Farh, J.L. (2008). A triad model of paternalistic leadership: the constructs and measurement. Indigenous Psychological Research in Chinese Societies, 14, 3-64.

Gul, S.E \& Ayse, B.G. (2008). The relationship between paternalistic leadership and organizational commitment: Investigating the role of climate regarding ethics, Journal of Business Ethics, 82, 955- 968. 
Iver, Mc. 1980. Jaring-jaring Pemerintahan. Jakarta: Aksara Baru.

Irawanto, D. (2008). The applicability of paternalistic leadership in Indonesia. Journal of Human Capital, 1(1), 67-80.

Meinanda, Teguh dan D.Akhmad. 1981. Ta n y a J a wab P e $n$ g a $n$ t $a r$ Antropologi. Bandung: CV. Armico.

Pudjiastuti, SR(2020), Etika Lingkungan, Depok: Penerbit Gemala,

Pudjiastuti, Sri Rahayu (2016). Metode Penelitian Pendidikan. Depok : Fatma Aji Depok.

Pudjiastuti,SR.(2019) Penelitian Pendidikan. Yogyakarta, Media Akademi.

Pudjiastuti,SR. M.Sutisna, Pat Kurniati, Sopian, \& S.Rumiati, "The Effect Policy Implementation Of Information Meteorologi Climatology And Geophysics On Economic Resilience", Systematic Reviews in Pharmacy 12(3), 166-175, 2021.

Rahmawati, Rita, Subair, Idris, Gentini, Dian Ekowati, Usep Setiawan. "Pengetahuan Lokal Masyarakat Adat Kasepuhan: Adaptasi, Konflik, Dinamika Sosio- Ekologis" dalam Sodality: Jurnal Transdisiplin Sosiologi, Komunikasi, dan Ekologi Manusia Vol. 2 No. 2. Agustus 2008. Hlm. 151190.

Siagian, Sondang P, (2006), Teori dan Kepemimpinan, Jakarta: Rineka Cipta.

Setiadi, Elly M. dan Usman, Kolip. 2011. Pengantar Sosiologi. Pemahaman Fakta dan gejala Permasalaha Sosial: Teori, Aplikasi, dan Pemecahannya. Jakarta: Kencana.

Soekanto, Soerjono. 2013. Sosoilogi Suatu Pengantar. Cetakan ke- 45 edisi revisi. Jakarta: Rajawali Press. 